\title{
Dividing a Child in Antiquity
}

\section{David Daube*}

$I^{\prime}$ MAKE A CLAIM upon a person, expecting something from him. I lay claim to an object, in competition with others. This distinction, however, is not absolute. On the one hand, I may make a claim upon an object-my dog, for example, or even my racing car, personified. On the other, I may lay claim to a person, as an object or objectified. In earlier times, there might be disagreement as to the ownership of a slave or villain; a number of creditors might dispute the services or body of an insolvent debtor; the ladies of a harem might enter into a contest over the husband-Leah "hired" Jacob from Rachel for a night." To list some familiar instances: the partners in a firm may fall out as to which is going to have the typist that day; two society hostesses as to which may invite the visiting royalty; one state may request from another the extradition of a criminal or permission for a minority to emigrate to the state preferring the request; men inay fight about a woman; angels and demons about a soul, alive or dead.2 Within the family, father, mother and governess may compete for a child; several children for a parent; father and son for the mother; mother and daughter for the father.

Often, though by no means always, where I lay claim to a person, I make a claim upon him at the saine time. Leah expected Jacob to honor her pact with Rachel: "Thou must come in unto me." A partner quarrelhing with the others about a typist may try to win by a direct appeal. So may a state asserting a right to a minority in another state, though hardly one requesting an extradition. So may a man fighting about a woman: the fifty sons of Aegyptus wrested from Danaus his fifty daughters, but one only of the bridegrooms survived the wedding-night-Lynceus, who won Hypermnestra's love. During a man's hife, angels and demons, besides warring for him against one another, do their best to enlist his cooperation, though death puts an end to the latter possibility. So long as a child is in the cradle, his competing elders will each lay claim to him; as he grows

* Dr. Jur., 1932, Gottingen University; Ph.D., 1936, Cambridge University; D.C.L., M.A., 1955, Oxford University; LI.D., 1958, Edinburgh University; Dr. h.c., 1963, Paris University; LL.D., 1964, Leicester University. Fellow of All Souls College; Regius Professor of Civil Law, Oxford University; Visiting Lecturer, University of California, School of Law, Berkeley, 1966-1967.

1 Genesis 30:16. See D. Daube, Studies in Brblical Law 16-24 (1947), and D. Daube, Concerning Methods of Bible-Criticism, 17 ARCHUV ORIENThíni 96-99 (1949).

2See, e.g., Rivière, Rôle du Démon au Jugement Particulier chez les Pères, 4 Revor Des SCIENCES Reutgreuses 43-58 (1924). His denial of pagan influence (Iramian, Egyptian) is not, however, acceptable. 
up, claims upon him will be added. The Father by Strindberg strikes a neat balance.

While marriage lasts, the law is reluctant to take up the conflicts over a child. In most systems, modern or ancient, control resides either with the father or with the mother. In a Roman marriage, in principle it is with the father, though at the latest, from Antoninus Pius (middle of the second century A.D.), sometimes it is with the mother. ${ }^{3}$ Save in extreme cases, it is left to spouses to make, or not to make, the necessary adjustments, without the help of the courts. On divorce or separation, in modern law, things become different. Though even at this stage control is as a rule adjudged to one of the parents, at least with regard to physical presence a child is practically divided. Not, fortunately, as Solomon proposed to divide a baby between two harlots each alleging to be his mother, ${ }^{4}$ or as the Twelve Tables allowed a defaulting debtor to be cut up by his creditors. ${ }^{5}$ A child, humanely, counts as indivisible with respect to his body; hence the division is in time, father and mother take turns. (Indivisible things have none the less been sphit up. Plutarch tells us of two brothers, joint heirs, so insensate as to halve a silver cup and a cloak. ${ }^{6}$ In English law, this starts with the equity courts expressing sympathy for, and now and then giving sone actual support to, a mother's desire for access to her child. ${ }^{7}$ Nowadays elaborate arrangements may be imposed to attain a fair result-with what success, who can say? ${ }^{8}$

In antiquity, the party who is out is out; no legal guarantee of access, shared holidays or the like. Where there are several children, the problem may be mitigated if the law distributes them between the parents. Some laws do-a distribution according to sex is suggested to, and rejected by, the Roman Emperors Diocletian and Maximian (end of the third century A.D.); evidently, the custom was known in some corner of the Empire. ${ }^{9}$ But many laws do not admit distribution, and in any case there may be only one child. Again, im sonie laws, a child below a certain age belongs to

3 DIGEST 43.30.1.3, 3.5 (ULP. LXXI ad edictum).

4 I Kings $3: 24,3: 25$.

5 Table III, pt. 6.

6 Piutarce, De fraterno atrore 483E.

7 In Ball v. Ball, 2 Simon 35 (1827), the spouses of a subsisting marriage lived apart, the husband keeping the child and entertaining an adulterous union. The Vice-Chancellor regretted his inability to help the inother. He said he was "nearly certain"-so not absolutely certain, which is remarkable-that Lord Eldon in a similar case (except that the estrangement was due to the husband's Catholicism) had refused the petition for access.

8 "'You're so stupid about children, Richard. They don't like being split,' said Molly." Lessing, The Golden Notebook, Free Women 1 (1962).

${ }^{9}$ Code 5.24 (A. D. 294); see Yaron, Reichsrecht, Volksrecht and Talmud, 11 RevuE InTERNationate des Drotts de I'ANTIQUTTE 296-98 (3d ser. 1964). 
the mother, above that age to the father. In medieval Jewish law ${ }^{10}$ a child belongs to the mother. But in the case of a son, once he is seven, the father may stop paying for his maintenance and thus, if she is poor, force her to hand him over: This is not, however, the kind of rotation which prevails in modern law. It simply means that at one point control may pass, for good, from one party to the other.

Why do we not find division in time-access or taking turns-in ancient systems? There are three reasons, interrelated, reinforcing one another. (One might think of a fourth, that children were less valued, but this would be fallacious.) First, in the absence of a developed apparatus of state, with means of investigation, communications and organs of enforcement, it would be too difficult to formulate or compel observance of such regulations. Secondly, ancient law is even more unwilling than modern to interfere in personal affairs; modern law looks away from struggles over a child during marriage, ancient law goes on looking away when the marriage has broken up. Thirdly, even during marriage in antiquity, that parent who is not in legal control no doubt receives less consideration than his modern counterpart. The enormous power of the head of family at Rome is proverbial - and he need not even be the father; if the father's father or grandfather is still ahive, it is he who has control. As for Greece, Agamemnon sacrificed Iphigenia while he was married to her mother; nor, for that matter, did Abraham ask Sarah's permission when he set out to offer up Isaac. True, this is not the kind of thing that happened every day-in historical times, it would no longer be permittedand writers like Aeschylus and Pindar represent Clytemnestra as deeply resentful. ${ }^{11}$ Still, even in Plato's age, a father could expose, cast out, a new-born child, regardless of the mother's wishes. ${ }^{12}$ Measured, then, by what people have to expect constante matrimonio, the situation soluto matrimonio is not so radically changed.

This third point goes far towards providing the answer to a further question that might be asked: granted it is not feasible for ancient law to assist the party who is out, why do we not come across more complaints or laments in general literature? As far as plays are concerned, the explanation is simple: divorced women do not appear on the Greek or Roman stage. This is no accident, but the subject cannot here be pursued. However, there would be ample room for exhibiting the plight of the forsaken parent in epic, history, moral essays, letters and so forth. That nothing of the sort occurs is accounted for by the harsh conditions during marriage, preparing the ground, so to speak, for those prevailing on divorce.

10 Matmontes, Mishiner Torat, Personal Status 21.1\%.

11 See B. Daube, Zu den Rechtsproblearen in Aischixlos' Agameanon 159-66 (1938).

12 Piato, Theaetetus $151 \mathrm{C}$. 
There is a tremendous exception: Medea. She is divorced, or about to be divorced, yet far from remaining confined to tales and poems, she is chosen as heroine by the greatest dramatists. Moreover, in Seneca, where she alone is exiled by King Creon, she pleads for time to bid her children a last farewell; ${ }^{13}$ indeed, at one point she asks Jason, the father, to let her take them with her. ${ }^{14}$ In Euripides, interestingly, Creon banishes her together with her children, so this ground of grievance does not arise (except for a moment, when the children are to be reprieved).

The case of Medea is hardly less extraordinary than that of Iphigenia. Even so, it definitely shows that the feelings were there. Only, most of the time, people put up with them, as they did with much other paim, without making a fuss. For the distress to come fully into the open, it needed outrageous circumstances like those depicted in this tragedy, with faithlessness, cruelty and hatred carried to extremes. Another conclusion is strongly suggested by this case. Authorities on ancient family law enphasize the financial obstacles in the way of divorce; say, a husband would have to return a substantial dowry. This is perfectly correct. But too hittle attention has perhaps been paid to the question of children. Surely, where the divorcing spouse would lose them-without the share he would normally be alloted by present-day law-that must act as a brake. As remarked above, medieval Jewish law assigns a child to the mother. Whatever may be the origin and intention of the rule, in a system which accords the husband an unfettered right to divorce his wife, and no corresponding right the other way round, the result must be to restore the balance soniewhat. ${ }^{15}$

The idea of rotation as such is quite familiar to antiquity. Oedipus uttered a curse on his two sons, that they should divide their inheritance with the sword. In order to escape this doon, they agreed to take turnsyear by year one would leave the country while the other ruled as king. Alas, it did not work. ${ }^{16}$ Fronl the beginning, the highest offices of the Roman Republic are each occupied by two colleagues-two consuls, two praetors-who take turns; at home, for instance, the two consuls of the

13 E.g., Seneca, Tragedies, Medea lines 288-93 (Miller ed. 1917).

14 Id. at lines 541-43. The words genetricem abstrahit natis, id. at lines 144-45, however, may express sorrow, not at her loss of the children, but at the latter's loss of their mother. Miller, taking natis as an ablative, equivalent to a natis, translates: "He (Creon) tears mothers from their children." Id. at 239. But natis may be a dative, dativus incommodi. The meaning may be: "He robs the children of their mother." Concern about the fate in store for the motherless children recurs, e.g., id. at lines 282-83.

15 How such pressures work may be gathered from as early a Biblical code as the Mishpatim. Here it is considered as not unlikely that a slave, if on release he would have to leave his wife and children with his master, will prefer to remain a slave together with them. Exodus 21:3-21:6, see D. Daube, The Exodus Pattern IN THe Birle 48-49 (All Souls Studies No. 2 1963).

10 E.g., Euripedes, Phoenissae. 
year change every month, in the field every day. ${ }^{17}$ Nor is the method restricted to the sharing of functions; it extends to objects and persons. Under Roman law, the owner of land on which water rises can give the right to it to two neighbors, for different times; ${ }^{18}$ or again, if joint holders of a usufruct wish to divide it-and it might be a usufruct over a slaveit can be done by mutual guarantees for alternate turns. ${ }^{10}$ The briefest mention may do for the strange ménage à trois carried on by Amphitryon, Jupiter and Alkmena. Two myths, however, involving the division of a child, deserve a closer look, though in neither is the child divided between the parents.

There is, first the rape of Persephone by Hades. Her mother, Demeter, disconsolate, prevails on Zeus to order her restoration. However, anyone who has tasted food in the nether world must return there again. Accordingly, for some months of the year she dwells with her mother and for some with her husband: in the Homeric Hymns ${ }^{20}$ she spends two thirds with the former, one third with the latter; according to Ovid ${ }^{21}$ half the year with each. (Obviously, a version written at Berkeley would have sent her down for a fortnight in December at most.) It is conceivable that, at one of the many stages of this myth, the accent lay less on the collision between the right of the mother and the magic of the food than on that between the right of the mother and the right of him who, without complying with the requisite forms, has yet in fact made the daughter his wife. Ovid tends a little this way: "If you are bent on a separation," says Jupiter (Zeus) to Ceres (Demeter), and "if you are set on breaking the bonds of bed once contracted."22 The ancient world knows the queerest gradations of patria potestas and wedlock. We need not even go outside Rome. To this day there is controversy as to the status, under the Twelve Tables, ${ }^{23}$ of a woman lawfully united to a man without confarreatio or coemptio and-an interesting feature this, in the present context-leaving his home once every year for three nights (or, maybe, the three All Souls' Nights) ${ }^{24}$ It would not be surprising if some of those who worked on the story of Persephone had been stimulated to a measure of legal or semi-legal speculation. In Ovid, it may be observed, Jupiter does act as "mediator," "arbitrator," medius. ${ }^{25}$

\footnotetext{
${ }^{17}$ See Jolowicz, Historical Introduction to Roman LaW 45 (2d ed. 1952).

${ }^{18}$ Digests 10.3.19.4 (PaUL VI ad Sabinum) 43.20 .5 pr. (JULInN IV ex Minicio).

19 Digests 10.3.7.10 (ULP. XI ad edictum).

202 (Eymn to Demeter) lines 400, 445-47, 463-65.

21 MetaMorphoses bk. 5, lines 564-67 FastT bk. 4, lines 613-14.

22 MetaMORPHOSES bk. 5, lines 529-30 (tanta cupido si tibi discidii est) bk. 4, line 602 (statque semel iuncti rumpere vincla tori).

23 Table VI, pt. 4.

24 See Jorowicz, op. cit. supra note 17, at 112-16, 549-50, Koschaker, Book Review, 63 ZetTsCartFT Der SAvtgny-STIFTUng 447 (Röm. Abt. 1943).

25 METAMORPHOSES bk. 5 , line 564.
} 
So here a child is divided in time between mother and husband or abductor. Curiously, the child, Persephone, figures also in the second myth to be considered, this time as a claimant, a foster-mother unwilling to return her charge. Aphrodite, angry with Smyrna, causes her to fall in love with her father and become guilty of incest. The girl is turned into the myrrh-tree-smyrna in Greek and Latin. Adonis is born of it, and Aphrodite hides the beautiful boy from the gods in a chest and entrusts him to Persephone, in the underworld. Persephone takes to the boy herself and refuses to hand him back. (Considering his broken home background, it is astonishing he did as well in the end as he did.) The case is brought before Zeus who, according to Apollodorus, decrees that for one third of the year Adonis should stay by himself, for another third with Persephone and for another third with Aphrodite. Adonis at once, understandably, makes over his own share to the latter. ${ }^{26}$ According to another version, probably of later origin, Zeus passes the case for decision to a lesser figure-the inuse Calliope in Hyginus, ${ }^{27}$ her son Orpheus in a papyrus. ${ }^{28}$ In this account, half a year's possession is awarded to each of the two htigants; and Aphrodite, enraged at not obtaining sole enjoyment, takes vengeance by instilling into the Thracian women or the Maenads such frenzied love for Orpheus that they tear him to pieces. It will be noticed that as in the rape of Persephone, there is a shift from a year two-thirds happy and one-third unhappy to a year equally divided. How far this has to do with the calendars of different cults or regions, how far with varying climatic and agricultural experiences, may be left open.

This nryth has distinct legal overtones. The dispute itself is less fantastic for early times than it looks today. Aphrodite saves a foundling, who may thereby turn into her slave, her foster-son or her adoptive son. The daughter of Pharoah did, it seems, adopt Moses: "And he becanie unto her a son." ${ }^{229}$ But we know of many cases where this does not happen, and besides, even adoption proper in antiquity can create a nore or less tight relationship. Anyhow, Aphrodite immediately hands the child on to Persephone, who doubtless becomes a foster-mother. A foster-mother who does her duty may acquire strong rights to the child. ${ }^{30}$ The case, then, is rather subtle: the foster-mother who has actually brought up the child defending her title against the woman-owner, first foster-mother or adoptive mother-from whom she received him.

26 Apoliodorus, Bibliotarea bk. 3 , ch. $14, \S 4$.

27 Hygnus, Astronomea bk. 2, ch. 7. Of course Zeus here is Jupiter and Aphrodite is Venus.

28 Pap. Berlin 13426, brilliantly edited by Schubart, Papyruskunde, in 1 EnNLEITUNG IN DIE Altertumstissenschaft pt. 9, pp. 42-43 (Gercke and Norden eds. 1924).

29 Exodus 2:10.

30 For a first orientation, see Koschaker, Adoption, in I REAJIEXIKON DER VORGESCEHCHTE 24-27 (Ebert ed. 1924). 
Especially in the later version, the manner in which the dispute is handled is reminiscent of the Greek action of co-owners for partition, an action initiated before an officer of state and then decided by "distributors," datetai. Needless to say, the litigation over Adonis is so unusual that it would be ill-advised to use it for settling the various controversies regarding the action for partition: did the official appoint the 'distributors' or did he request a court to do so?; was the action available to any coowners or only to joint heirs?; was it available even where one of the parties denied the very existence of co-ownership, maintaining that he was the sole owner? ${ }^{31}$ To solve these problems, we must still rely on the legal sources proper.

Perhaps the verdict in the myth establishes something like a joint usufruct, to be exercised in rotation. Or maybe it makes the competing wonen into a kind of co-owners, defining the precise extent of each one's sliare. In systems less rigidly analytical than the classical Roman, coownership with the parties alternately owning for a time would be quite feasible. ${ }^{32}$ Nor would the grant of a third of the year to Adonis himselfthis we find in the earlier version-necessarily conflict with this construction. He, too, is a co-owner; for that third he belongs to himself: in ancient law, to belong to oneself and to be free are often the same thing. ${ }^{33}$ We may indeed detect here an allusion to paramone, "staying with the master." This is the designation of a widespread ancient Greek practice: a slave is freed and therefore belongs to limself, at the same time remaining bound to continued service and therefore belonging to his master. (A debtor or apprentice could be in a similar state of paramone. $)^{34}$ Apollodorus employs the verb menein para, "to stay with," for the three parts of the year Adonis is "to stay with hinself, with Persephone and with Aphrodite." Admittedly, paramenein would be even closer to paramone. Of

31 See J. W. Jones, The LAW and Legal Theory of the Greers 210-12 (1956), 2 L.PSIUS, Das ATtISCEE RECHT UND ReCHTSVERfakreN pt. 2, pp. 576-77 (1912); Pappulias, Book Review, 26 ZETTSCERTIFT DER SAvtGNY-STIFTUNG 550-52 (Röm. Abt. 1905).

32 On the institution of co-ownership in functional shares, see Koschaker, Book Review, 58 ZETTSCHRIFT DER SAVIGNY-STIFTUNG 254-66 (Röm. Abt. 1938); Koschaker, Uber einige griechische Rechtsurkunden aus der. östlichen Randgebieten des Hellenismus, in 42 AвEANDIUNGEN DER SÄCHSISCHEN AKADEMTE 46-48 (Phil.-Hist. Klasse 1931-1934).

33 For Greek law, see Koschaker, Uber einige griechische Rechtsurkunden aus den östlichen Randgebieten des Hellenismus, in 42 ABHANJIUNGEN DER SÄCHSTSCHEN ARADEMIIE 47, 55, 74 (Phil.-Hist. Klasse 1931-1934). According to Mismener GrTtIN 9.3 the writ of emancipation of a slave-woman runs: "Lo, thou art a free woman, thou art unto thyself." In the bill of divorcement supplied by MatMONIDES, MrsHNEn TORAR, Divorce 4.12, the following passage occurs: "That thou mayest be authorized and empowered over thyself, to go and be married to any man."

${ }^{34}$ See J. W. Jones, op. cit. supra note 31, at 212-15; Berneker, Paramone, in 18 REAI ENCXCLOPÄDIE DER CLASSischeN ALTERTUMSWISSENSCteAfT pt. 2, cols. 1212-14 (Pauly \& Wissowa eds. 1949); Koschaker, supra note 33, at 16-32. 
course, the transfer of his share to Aphrodite spells the end of any pretensions on his part to independence.

The vengeance of the goddess in the later account is a beautiful example of punishment fitting the crime. She loves Adomis so much that to be given turns is a deep hurt. Orpheus now, through her doing, is loved by a horde of women so passionately that they will not contemplate a peaceful arrangennent; they dismember him. The physical division instead of division in time, threatened by Solomon by way of bluff (and successfully avoided so far by the Beatles), is here translated into reality. If it is Orpheus' mother Calliope who rendered the offensive decision, the retribution is even more precise: she is being taught what it means to have to "share" a beloved child.

Both in the story of Persephone and that of Adonis, the parties laying clain to the child are thought of as making claims upon her or him at the same time. Already in the Homeric Hymns Hades exerts himself to win over Persephone, ${ }^{35}$ and in some elaborations of the inyth she actually prefers his company to her nother's. ${ }^{36}$ Lucan goes very far: Persephone hates her mother and loves her abductor with an unholy love; ${ }^{37}$ and indeed, her mother, because of some terrible thing the daughter has undergone, does not want her back. ${ }^{38}$ The latter feature is unique, and we are in ignorance of what is behind it. Lucan's own relation to his nother seems to have been miserable; this remains probable even if the horrid detail in his life recounted by Suetomus should be exaggerated or untrue. ${ }^{39}$ As for Adonis, the earlier account of the inyth represents Aphrodite as eminently successful in her dealings with hin1: he himself assigns his own third to her.

These two myths, it may be said, show the modern method of dividing a child hovering on the verge of materialization, like hope under the rim of Pandora's jar. Relatively little, one feels, would be needed to make it part of legal life. As it is, centuries had to pass before the courts were in a position to make practical use of the idea.

The writer would be happy if Professor Albert Ehrenzweig, levem non aversatus honorem, found these reflections of some interest.

352 (Hymn to Demeter) lines 361-69.

36 VtrGII, Georgics bk. 1, line 39; Colungetia DE dE rustica bk. 10, lines 272-74.

37 Patarsatia bk. 6 , lines $698,740-41$.

38 Id., bk. 6, lines $741-42$.

39 Orthodox opinion (see Anderson, Lucan, in OxFord ClassicaI Dictionary 514 (1949)) rejects it as a fabrication, accepting the conclusions of Plessis who wrote at the beginning of the century in LA PoÉsIe IATINe 547-49 (1909). But Plessis is highly speculative. For him, this detail is an invention of Nero: Lucan had pretended to be the Emperor's equal as a poet; let him live on in history, the Emperor decided, his equal as a monster of a son. 